\title{
Choice of Livelihood Strategies and Its Determinants in Pastoralist Area of Bale Zone: The Case of Sawena District, Oromia, South East Ethiopia
}

\author{
Mesfin Bekele Gebbisa ${ }^{1 *}$, Gemachu Mulatu² \\ ${ }^{1}$ Oromia Forest and Wild Life Enterprise Arsi Branch, Arsi Nagele, Ethiopia \\ ${ }^{2}$ Department of Economics, Madda Walabu University, Robe, Bale, Ethiopia \\ Email:`bekelemesfin4@gmail.com, geme.chu@yahoo.com
}

How to cite this paper: Gebbisa, M.B. and Mulatu, G. (2020) Choice of Livelihood Strategies and Its Determinants in Pastoralist Area of Bale Zone: The Case of Sawena District, Oromia, South East Ethiopia. Open Access Library Journal, 7: e6737. https://doi.org/10.4236/oalib.1106737

Received: August 21, 2020

Accepted: September 22, 2020

Published: September 25, 2020

Copyright $\odot 2020$ by author(s) and Open Access Library Inc.

This work is licensed under the Creative Commons Attribution International License (CC BY 4.0).

http://creativecommons.org/licenses/by/4.0/ (c) (i) Open Access

\begin{abstract}
The carrying capacity of pure pastoralist livelihood strategies only to attain food and livelihood security is extremely declining from time to time. Diversifying livelihood strategies at current time become a standard phenomenon within the study area. The general objectives of this study are, therefore, to characterize the existing livelihood strategies adopted by pastoral households and its determinants in the Sawena district, Oromia National Regional State, Southeast Ethiopia. To examine this general objective, the study employed descriptive statistics and bivariate probit model. Both primary and secondary data sources were used for the study. For the purpose of this study primary data collected from 350 sample households through face-to-face interviews. In addition, focus group discussions and personal observation are used. Relevant secondary data were also obtained from concerned zonal and district government offices. Descriptive statistics was applied to characterize livelihood strategies of the sample households. The finding of the survey result indicates that about $66.57 \%$ of households engaged on pure pastoralist activities, whereas about $33.43 \%$ were relying only on agro pastoralist activities to achieve their livelihood goal(s). This result indicates that most of the pastoral household heads are engaged in pure pastoralist activities rather than diversifying toward agro pastoral and related non-pastoral livelihood activities. Bivariate probit model applied to investigate factors influencing the households' choice of livelihood strategies. The Econometric model result indicated that age, family size, dependency ratio, tropical livestock unit of holding, access to mass media, distance from the nearest market, access to rural electrification, access to irrigation, total farmland size and access to
\end{abstract}


rangeland were determining pastorals' choice of livelihood strategies. The results of this study suggest that development interventions, policies and capacity-building activities should be designed to suit the felt needs and circumstances of different groups of pastorals households.

\section{Subject Areas}

Economics

\section{Keywords}

Livelihood Capital Asset, Livelihood Strategies, Pastoralist, Bivariate Probit Models, South East Ethiopia

\section{Introduction}

Pastoralists in Ethiopia live in the arid or semi-arid lands, which cover about $63 \%$ of the country [1]. Regionally, over $97 \%$ of the pastoral population lives in Somali, Oromia, Afar and Southern Region States. Besides the mainly known pastoral regions, others just like the Gambella and Benishangul-Gumuz Regional States have pastoral communities although these regions at the western end of the country have predominantly a shifting cultivation agricultural system. Pastoralists have found distributed over 122 districts of the country. Most of these districts are located in very remote and marginalized areas of the country, whose livelihoods depend on their intimate knowledge of the surrounding ecosystem and on the wellbeing of their livestock [2].

However, despite their economic contribution, there has been a fundamental misunderstanding of the pastoral production system in Ethiopia (like in many other countries in Africa). But, the pastoralists are contributing to the economy in sort of domestic and international export of livestock and livestock products. The livestock sector contributes 12\% - 16\% of the Ethiopia GDP and 30\%-35\% of the agricultural GDP. In Ethiopia, livestock GDP within the pastoralist and drought-prone highland areas (roughly like the arid and semi-arid zones) is about 15 percent of national agricultural GDP. About 50 percent of livestock value added comes from these zones; overall, livestock accounts for about $30 \%$ of national agricultural GDP [3].

More than 80 percent of people in Ethiopia rely on agriculture and livestock for their livelihoods; however, the frequency of droughts over the years has left many communities particularly vulnerable. Consecutive seasons of poor rainfall in southern and South Eastern pastoral areas have severely limited feed and water availability. This resulted in livestock deaths that have driven rising food insecurity and malnutrition rates, which are in large part a consequence of insufficient and underfunded livelihoods response. Displacement has increased in pastoral areas because of significant livestock losses, and for many, livelihood abandonment, extreme destitution and protracted reliance on relief aid are real 
risks. For some, this could be temporary, but they require urgent support to regenerate their herds or access alternative livelihood options [4].

Livelihoods in Pastoral area of Ethiopia are primarily based on extensive livestock production and most cash earnings come from sales of livestock and livestock products such as milk, hides and skins. However, the impact of drought, increasing insecurity, and famine has led to a growing emergence of sedentary life and experimentation with alternative livelihoods. Pastoralists in Ethiopia increasingly pursue non-pastoral income strategies to satisfy consumption needs and to support against shocks caused by climatic fluctuation, disease, market failure, and insecurity [4].

In the same way, pastoral area of Bale zone in general and Sawena district in particular, is constrained by diverse natural, social and economic problems including recurrent drought, lack of basic infrastructure, conflict, and they have low resilient capacities to cope with and recover from such vulnerable situations [5]. Due to this, majority of population livelihoods in the pastoral area of the zone in most seasons of the year are depending on food assistance of the government's and different development partners [6].

However, governmental and non-governmental organizations with permanent and pilot project in Sawena district had been spending many resources from year to year but they are not able to bring a feasible change on the choice livelihood strategy of the pastoral community. This is may be because of lack of information on what exactly constitutes the livelihood strategy of different socio-economic groups and the reason behind household livelihood strategies choices and natural factors such as climatic changes like drought and others. The lack of such information and wrong approach in turn was constraining effective decisions on the type and nature of interventions and the target beneficiaries [7].

In line with this, different households adopt different livelihood strategies according to their particular asset and asset status perceptive towards specific livelihood strategies. However, there is not sufficient empirical research, which conducted concerning this issue in the study area and even in Bale zone except Getachew [8] study on livelihood diversification strategies, determinants and challenges for pastoral and agro-pastoral communities in Rayitu and Madda Walabu district of Bale zone, as I know or my knowledge concerned. This study focused only on agro pastorals kebeles by neglecting pure pastorals kebeles of household livelihood activities.

Most of empirical study on choice of livelihood strategies analysed using multinomial logistic regression model, multivariate probit and, multivariate Tobit model where as this study used bivariate because in the study area due to polygamy practise households jointly engage on agro pastoralist and pure pastoralist livelihood strategies in different agro climatic area.

Therefore, this study was examined the choice of livelihood strategies and its determinants in pastoral area of Bale zone in the case of Sawena district in order to address the choice of livelihood strategies. Because there was no research based 
information on how households could closed this gap and to inform the practice of none traditional livelihood strategies adoption among the pastoralists.

\section{Methodology}

\subsection{Type and Source of Data}

Quantitative and qualitative data collected from both primary and secondary sources. The secondary data source for this study obtained from various sources of published and unpublished journal, government and nongovernment reports, article, book, maps and other relevant materials from Sawena District Pastoral Development Offices, Sawena District Administrative Offices, Peasant association (kebeles) office in Sawena district, Bale Zone Agricultural and Natural Resource office and Bale Zone Pastoral Area Development Office, and others.

The primary data collected using questionnaire; focus group discussion and personnel observation from the sampled households, key informants such as kebele administrators, communities' elders, veterinary extension, youth, women and development experts in the district. Such data include demographic characteristic, socio-economic characteristics, livelihood activity of pastoral area, etc.

\subsection{Method and Instrument of Data Collection}

Six enumerators with undergraduate qualifications/minimum of grade 10 was hired by the researcher to assist data collection process. They had trained on the contents of the questionnaire one day prior to the household survey. In addition; the researcher was supervise and coordinate all the data collection process.

The study was employees' triangulation of data collection strategy in which four data collection methods such as questionnaires, focus group discussion, personal observation and secondary source to ensure complementary strengths and improvement in data validity and reliability.

According to University of Illinois [9], the triangulation of data suggested that in recognition of the imperfections in each data collection method, social triangulation enables crosschecking of gathered data that increases data validity as one set of data against data from another collection method. It was also important not to heavily rely on one data source given the high likelihood of individual bias. Gathering through a mix of different approaches ensured balance results. Diagrammatically, triangulation of data collection strategy is elaborating as follows as by Figure 1.

\subsubsection{Structured Questionnaires}

The structured questionnaire consisting of both closed and open-ended designed and administer to households for primary data collection. The advantage of the structured interview was that it takes place over a short period of time [10]. The questionnaire was designed in order to collect both qualitative and quantitative data. The questionnaire then administered to respondents through face-to-face interviews. 


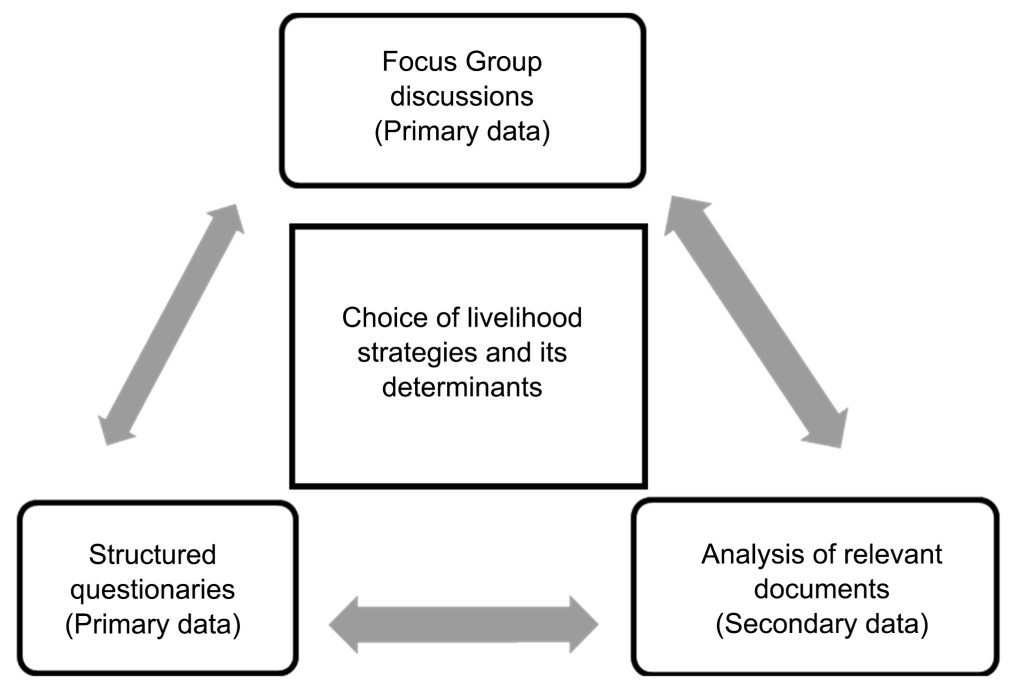

Figure 1. Triangulation of data collection strategy.

However, face-to-face interview had chosen because they had several advantages over the other methods. According to Bless and Smith [11], an interviewer-administered interview reduces omission of difficult questions by respondents. In addition, it reduces the problem of word or question misinterpretation (misunderstandings) by respondents and it could administer to respondents who can neither read nor write. In addition, the presence of the interviewer increases the quality of the responses since the interviewer can probe those more specific answers [12]. In other words, the use of interviewer-administered questionnaires ensures minimal loss of data when compared to the other methods.

The questionnaire in this study was consisting of five assets of the livelihood strategies namely: 1) human assets; 2) financial assets; 3) physical 4) social assets 5) natural assets. This was aim at collecting data to characterize pastoral livelihoods, with particular focus on the activities in the study area. The questionnaires pre-test and adjust before the interviews of the sample households. During the survey, respondents are not identified by name or location in order to maintain confidentiality.

In this study 350-sample respondent from six sample kebeles was participated to fill structure questionnaires. In the absence of the head, the spouse or any family member who was directly involved in the pastoral livelihood activities was fill the questionnaire. The main respondent provides most of the information, but allows consulting other household members where necessary.

\subsubsection{Focus Group Discussion}

Focus group discussions recognized to be a useful tool in research. A focus group discussion meant to generate qualitative information through an organized discussion with a selected group of individuals on a particular topic [13]. Thus, as noted by Webb and Kevern [14] all definitions place emphasis on interaction among participants as a way of accessing data that would not emerge if other methods used. Interaction gives the method a high level of validity because 
what participants say confirmed, reinforced or contradicted within the group discussion.

Some researchers suggest that focus group discussions can be comprised of up to fifteen people [15]; however, the recommended number of people per group was usually six to ten [16]. Focus group sessions usually last from one to two hours. The meetings can be held in a variety of places ideally there should be conducted at an accessible place where the participants hold their regular meetings. Neutral locations can be helpful for avoiding either negative or positive associations with a particular site or building [17]. Focus group discussions enable researchers to draw upon respondents' attitudes, feelings, beliefs, experiences and reactions in a way in which would not be feasible using other methods such as observation, one-to-one interviews or questionnaire surveys.

In this study, six (6) focus group discussions was conducted at six selected sample kebeles venues. Each discussion group has 12 randomly selected participants. In total, 72 participants comprising women, youths and men were separately engaged in discussions to ensure balance representation and input Judgment or quota sampling was employ according to the researcher's judgment to ensure participants with the sufficient demographic and socioeconomic representation.

\subsubsection{Personal Observation}

The study employs direct personal observation to deepend understanding of issues and observes the interaction of people in their natural setting. Informal observation and interaction with community members during the research period enables me to establish a relationship of trust with research participants which facilitated greater access to "inside" knowledge, thereby enhancing the credibility of the findings [18]. Observations made were comparing and utilize during focus group discussions and questionnaires to enrich research findings. The personnel observation was taken place depending on checklist of the researchers.

\subsubsection{Secondary Source}

Secondary data is the data that had already collected by and readily from other sources. Such data was cheaper and more quickly obtainable than the primary data and may be available when primary data not obtained at all. Secondary data enjoys the advantage of being available, effortlessly, rapidly and inexpensively. Primary data takes a lot of time and the unit cost of such data was relatively high [19].

The study was also harness various information sources and documentation on the subject matter and the study area from the Internet as well as from different government office and non-government organization. Information had also gathered by reviewing government reports, news items and research findings from previous studies in the area of choice of livelihood strategies. Secondary data gathered from previous research on the subject enabled the researcher to understand the research area better, thus assisting the researcher in shaping the research approach, as well as the gaps that need to fill in by the research. 
More secondary data obtained from the Internet, especially from the websites of various development institutions.

\subsection{Sample Size Determination}

In the Sawena district, there were about 88,765 and 16,200 total population and households, respectively. The sample size was being determining using Kothari [20]. equation. The equation helps to determine the sample size when the population size is finite. The equation explained as follows:

$$
n=\frac{z^{2} \cdot p \cdot q \cdot N}{e^{2}(N-1)+z^{2} \cdot p \cdot q}
$$

where,

$Z$-Values of standard variant at $95 \%$ confidence interval $(Z=1.96)$.

$P$-is the estimated proportion of an attribute that is present in the population.

$q$-is the estimated proportion of an attribute that is not present in the population.

e-Margin of error considered is $5 \%$ for this study.

$N=$ population

$$
n=\frac{(1.96)^{2}(0.5)(0.5)(3871)}{(0.05)^{2}(3871-1)+(1.96)^{2}(0.5)(0.5)}=350
$$

As shown in Table 1, the selected six kebeles namely Burka Daro, Arele, Boditi, Arda Gelma, Dolicha and Micha household population are 3871. Using the above formula the total household sample size of respondent was 350 household. The Household sample respondent at kebeles level selected proportionally based on household number. i.e.

$$
\begin{aligned}
& \text { Sample hh at kebeles level } \\
& =\frac{\text { Total number kebeles household }{ }^{\star} \text { Total household sample }}{\text { Total number of household }}
\end{aligned}
$$

Table 1. Household sample respondent at kebeles level [21] * for total household only.

\begin{tabular}{cccc}
\hline S.N & Name of Kebeles & Total house hold & Sample household \\
\hline 1 & Mica & 1058 & 95 \\
2 & Arda Gelma & 708 & 64 \\
3 & Dolcha & 715 & 65 \\
4 & Boditi & 365 & 33 \\
5 & Harele & 540 & 49 \\
6 & Burka Daro & 485 & 44 \\
Total & & 3871 & 350 \\
\hline
\end{tabular}

Source: Sawena district Planning and Economic Development commission. 


\subsection{Sampling Frame and Sampling Procedure}

A household was used as the basic unit of the survey and the household head was the unit of observation. In this regard, a household was defined as a group of people living together, making common arrangements for food and other essentials for a living [22]. In order to set sample frame, the list of households recoded by the kebeles was be used as sampling frame. According obtained data from six sample-selected kebeles administration 3871 households found in the area.

This study was employed multi-stage sampling technique in which both purposive and random sampling techniques applied. In the first stage out of 9 pastoral districts of Bale zone, Sawena district selected purposively based on the potential/opportunity of livelihood activities but it is not yet utilized by household. In this area a number of stockholders are working to improve the wellbeing's of the people but the lives of people were not yet improved and going well as expected to be due to this and others. I am motivated to know the reason behind fail of wellbeing improvements. For this, I do have good knowhow about the area. Therefore, Sawena district was my research target/focusing area.

In the second stage, out of the 29 administrative kebeles of the district six are purposively selected based on proximity to the center of the district, occupational structure, agro ecological location and accessibility of social infrastructure development especially water, road and market. These sample selected kebeles are namely Burka Daro, Arele, Boditi, Arda Gelma, Dolicha and Micha.

Finally, the households were selected from each kebele based on sampling frames prepared from the housing registry available at the kebeles administration offices by using simple random sampling. The number of households that selected from each sampled kebeles was be determined in proportion to the respective total household size in each kebeles.

\subsection{Method of Data Analysis}

In order to achieve the stated objectives of the study, the survey data was sort out, edit, coded, organize, summarize and analyze using descriptive and econometric models. The data analysis was conducted using STATA software Version 13.1 to generate the parameter estimates.

\subsubsection{Descriptive Statistics}

Descriptive statistics namely frequencies, percentages and means are used. The bar chart, pie chart and frequency tables used to represent or to show the result. In order to determine whether the mean difference between two groups is statistically and significantly different from zero employed independent $t$-test because independent variable has related groups.

\subsubsection{Econometric Models}

In order to undertake comparative analysis, the study was employing econometric models of bivariate probit regression model. The bivariate probit model was a generalization of the probit model used to estimate two correlated binary out- 
comes jointly. Model would be appropriate for jointly predicting these two choices on a private an individual specific basis.

In order to achieve the objective of this study bivariate probit regression model is used because the majority of pastoral household in the district adopt seasonal livestock migration for search of grazing and water for their livestock during dry season and male headed household move from place to place with their livestock. Thus in this condition male-headed pastoralist married another wife that have settled in the area and start to engage/participate in other livelihood activities. That is Agro pastoralist start to engage in pure pastoralist livelihood activities and vice versa until back to their original home. In this case, household lead jointly the existing livelihood strategies.

The bivariate probit analyses were used to examine the relationship between two or joint livelihood strategies (dependent variables) that are determined by the five capital (human, financial, social, natural and physical capital) (Independent variable) accessible and ownership to the households.

Following the approach taken by Greene [23], the bivariate probit model for this study characterized by a set of m binary dependent variables $Y_{m i}$ such that:

$$
y_{m i}^{*}=\beta_{m i}^{*} X_{m i}+\mu_{i}
$$

where $Y_{m i}^{*}(m=1 \cdots k)$ represent the dependent variable of livelihood strategies selected by the $i^{\text {th }}$ pastoral households $(i=1 \cdots n)$. The dependent variables are binary variable indicating whether choice of livelihood strategies are made through the relevant livelihood activities. The livelihood strategies aggregated into two groups: pure pastoralist (livestock rearing) and Agro pastoralist. Each pastoral household can use one or both livelihood activities. $x_{m i}$ is a $1 \times k$ independent variable that affects the choice of livelihood strategies decision and $\beta_{m i}$ is a $k \times 1$ vector of unknown parameters to be estimated $\mu_{i} \quad i=1, \cdots, i$ are the error terms distributed as bivariate normal, each with a mean of zero, and variance covariance matrix $\mathrm{V}$, where $\mathrm{V}$ has values of 1 on the leading diagonal and correlations. The aforementioned equation was a system of $m$ equations shown in the following equations:

$$
\begin{gathered}
y_{1 i}^{*}=\beta_{1} x_{1 i}+\mu_{1 i} \\
y_{2 i}^{*}=\beta_{2} x_{2 i}+\mu_{2 i}
\end{gathered}
$$

$y_{1 i}^{*}$ denotes the $I^{\text {th }}$ household who participated in pure pastoralist livelihood and $y_{2 i}^{*}$ denotes the $i^{\text {th }}$ household who participated in agro pastoral livelihood.

The latent dependent variables observed through the decision to choice of livelihood strategies or not $\left(y_{k i}\right)$ such that:

$$
Y=\left\{\begin{array}{l}
1 \\
0
\end{array} \text { if } y_{k}^{*}>0, k=1,2\right. \text { other wise }
$$

In bivariate model, where the choice of livelihood strategies was possible, the error terms jointly follow a bivariate normal distribution (BVN) with zero conditional mean and variance normalized to unity (for identification of the para- 
meters) where $\left(\mu_{1 i}, \mu_{2 i}\right) \mathrm{BVN} \sim(0, \Omega)$ and the symmetric covariance matrix $\Omega$ was given by:

$$
\Omega=\begin{array}{cc}
1 & \rho_{12} \\
p_{21} & 1
\end{array}
$$

where $\rho$ represents the unobserved correlation between the stochastic components of the error terms concerning choice any two of the livelihood strategy equations estimated in the models. In Equation (2), the correlation between the stochastic components of different livelihood strategies is represented by the off-diagonal elements (example: $\rho_{12}$ and $\rho_{21}$ ) in the variance covariance matrix [24]. The assumption of the unobserved correlation between the stochastic component of the $k^{\text {th }}$ and $m^{\text {th }}$ type of livelihood strategies means that Equation (1) gives a bivariate model that jointly represents decisions to choice a particular livelihood strategy. This specification with non-zero off-diagonal elements allows for correlation across the error terms of several latent equations, which represent unobserved characteristics that affect choice of other alternative adaptation strategies.

The maximum likelihood function of the probabilities that every outcome success was explained as

$$
\begin{aligned}
& \operatorname{Pr}(P P=1, A P=1)=\Phi\left(\beta_{1} X_{1}, \beta_{2} X_{2}\right) \\
& \operatorname{Pr}\left(v_{1 i} \leq \beta_{1} X_{1} \leq \beta_{2} X_{2}\right)
\end{aligned}
$$

where $\Phi_{2}$ is standard normal distribution, PP is Pure Pastoralism, AP is Agro pastoralists.

The marginal effects of explanatory (dependent) variable on the propensity to choice livelihood strategies on each of the livelihood activities calculated as:

$$
\frac{\partial p_{i}}{\partial x_{i}}=\phi\left(X^{\prime} B\right) \beta_{i}, i=1,2, \cdots, n
$$

where $\rho_{i}$ is the probability (likelihood) of event $i$ that is (increased choice of each livelihood strategies), $\phi(\cdot)$ is the standard univariate normal cumulative density distribution function. $X$ and $\beta_{i}$ are vector of regressors and model parameters respectively [25] definition of variables and hypothesis.

\subsubsection{Dependent Variables}

The study considered two livelihood strategies or activities in pastoral area, including pure pastoralist and agro pastoralist as a dependent variables.

If the choice of the household lies in livelihood strategies, rational household head chooses between the two mutually exclusive livelihood strategy alternatives that offer the maximum utility. The binary dependent variable for the determinants of rural households' choice of livelihood strategy defined as follows:

$Y=1$ if the choice of household is livestock rearing otherwise zero,

$Y=2$ if the choice of household is Agro pastoralist livelihood otherwise zero,

Pure pastoralist livelihoods: these are the most common, whereby households rely on rearing camels, cattle, sheep and goats. The survival, number and condition of livestock determine the household's wealth and the ability to con- 
tinue its livelihood pattern.

Agro-pastoral livelihoods: it combines extensive livestock rearing and rain-fed cereal production (sorghum, wheat, maize, barley, teff and other cereals) for household consumption.

\subsubsection{Independent Variables}

As indicated in Table 2, it hypothesized that the livelihood strategies were a function of a set of factors that included in the model. The independent variables included in the models and hypothesized are ages of the household head, sex of household head, total family size of the household, education status of the household head, dependency ratio of the household, access to credit, livestock holding, total farm land size, asset value, membership of Cooperative, access to Mass Media, access to veterinary extension service, distance to market, access to electricity, access to range land and access to irrigation.

Table 2. Summary of independent variables.

\begin{tabular}{|c|c|c|c|c|}
\hline № & Variable name & Variable code & Definition and unit of measurement & Hypothesis \\
\hline 1 & Sex of the household head & SEX & Sex is a dummy variable assigned one if a head is male and 0 otherwise. & Negative \\
\hline 2 & Age of the household head & AGE & Age of household head in years given in continuous variables $(1,2,3, \ldots)$ & Negative \\
\hline 3 & $\begin{array}{l}\text { Total family size in the } \\
\text { household }\end{array}$ & FAMLSIZ & $\begin{array}{l}\text { Total number of household members takes the value of }(1,2,3, \ldots) \\
\text { It is a continuous variable }\end{array}$ & Positive \\
\hline 4 & $\begin{array}{l}\text { Education status of the } \\
\text { household head }\end{array}$ & EDUCHH & $\begin{array}{l}\text { It is a continuous variable measured in education level of household } \\
\text { (quantified by number of years of schooling) }\end{array}$ & Positive \\
\hline 5 & $\begin{array}{l}\text { Dependency ratio of } \\
\text { the household }\end{array}$ & DPRHH & $\begin{array}{l}\text { It is a continuous variable measured in percent a No of children below } 15 \text { years } \\
\text { and aged persons above } 65 \text { years of age in a } \mathrm{HH} \text { given in values as } 0,1,2,3, \ldots\end{array}$ & Positive \\
\hline 6 & Access to credit & CREDIT & A dummy variable, which takes 1 if a household access 0 other wise & Positive \\
\hline 7 & $\begin{array}{l}\text { Tropical livestock } \\
\text { unit of holding }\end{array}$ & TLU & $\begin{array}{l}\text { It is a continuous variable and measured by Tropical Livestock Unit } \\
\text { (TLU Size of livestock owned by HHHs }\end{array}$ & Negative \\
\hline 8 & Asset Value & ASSET & $\begin{array}{l}\text { It is a Continuous variable and estimated value of all the physical assets } \\
\text { (except land) owned by a household (in birr) }\end{array}$ & Positive \\
\hline 9 & $\begin{array}{l}\text { Membership of } \\
\text { Cooperative }\end{array}$ & MEMCOP & $\begin{array}{l}\text { A dummy variable, which takes } 1 \text { if a household participate in } \\
\text { cooperative } 0 \text { other wise }\end{array}$ & Positive \\
\hline 10 & Access to Mass Media & MEDIA & A dummy variable, which takes 1 if a household access 0 otherwise & Positive \\
\hline 11 & $\begin{array}{l}\text { Access to Veterinary } \\
\text { extension service }\end{array}$ & ACCEXT & $\begin{array}{l}\text { A dummy variable, It refers to extension agent contact with farmers } \\
\text { which takes } 1 \text { if a household access } 0 \text { otherwise }\end{array}$ & Positive \\
\hline 12 & $\begin{array}{l}\text { Distance from the } \\
\text { nearest market }\end{array}$ & DISMARKT & $\begin{array}{l}\text { It is a continuous variable designating } \mathrm{HHs} \text { proximity to the } \\
\text { nearest market center measured in kilometre. }\end{array}$ & Negative \\
\hline 13 & Access to electricity & ACCELCT & A dummy variable, which takes 1 if a household access 0 otherwise & positive \\
\hline 14 & Access to Irrigation & IRRGT & A dummy variable, which takes 1 if a household access 0 otherwise & Positive \\
\hline 15 & Total farm land size & FLNDSZ & $\begin{array}{l}\text { Land size owned by the household in hectares local unit takes the } \\
\text { value of }(1,2,3, \ldots) \text {. It is a continuous variable }\end{array}$ & Negative \\
\hline 16 & Access to Rangeland & RNGLND & A dummy variable, which takes 1 if a household access 0 otherwise & Negative \\
\hline
\end{tabular}




\section{Result and Discussion}

\subsection{Household Livelihood Strategies}

In the study area, pastorals have adopted two different strategies to achieve their livelihood outcomes. These are pure pastoralist and agro pastoralist strategies. Other means of livelihood strategies are not well organised and enhanced in the community. Table 3 gives a breakdown of the different livelihood strategies that households pursue in the study area.

As observed from Table 3, the survey result about $66.57 \%$ of the total sample house households depend solely on pure pastoralist (livestock rearing) for their livelihood strategies. The remaining, parts of the respondents (33.43\%) depends their livelihood activities on agro pastoralist (livestock rearing and crop production jointly). The agro pastoralist activities help pastoral household to fill income and food gap that pure pastoral activities unable to do. Diagrammatically, the break down is indicate as the follows in the pie chart (Figure 2).

From Table 3 and Figure 2, we can conclude that, most of the pastoral household heads are engaged in pure pastoralist (livestock rearing) activities rather than diversifying in the agro pastoral and related non-pastoral livelihood activities.

\subsection{Mean Comparison of Household Livelihood Strategies}

In order to determine whether the mean difference between two groups is statistically and significantly different from zero employed independent t-test because independent variable has related group. Thus, t-test is appropriate instead of one way ANOVA due to related independent variable.

Table 3. Sampled pastoral households' livelihood strategies.

\begin{tabular}{ccc}
\hline Livelihood strategies & Number in sample HH & Proportion of sampled HHs (\%) \\
\hline Pure Pastoralist & 233 & 66.57 \\
Agro pastoralist & 117 & 33.43 \\
Total & 350 & 100 \\
\hline
\end{tabular}

Source: own survey.

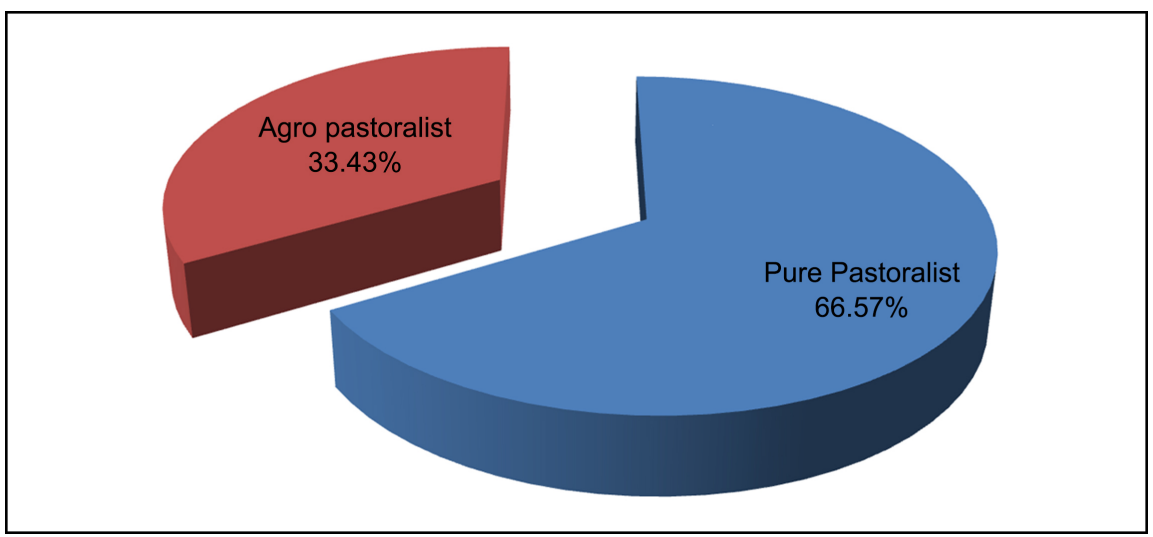

Figure 2. Livelihood strategies in the study area. Source: own survey data (2019). 
According to descriptive analysis, some variations observed between two livelihood groups in terms of households' human, social, financial, physical and natural capital asset characteristics. The two groups differ to some extent in their Sex, age, family size, education status, dependency ratio, tropical livestock unit of holding (TLU), asset value, membership of cooperatives, access to mass media, access to credit, distance from the nearest market, access to electricity, access to irrigation, total farm land size and access to rangeland.

The participant and non-participant mean of pure pastoralist and agro pastoralist strategies differ from variables to variables. As shown in Table 4, in pure pastoralist strategies, the participant and non-participant mean difference by the tropical livestock unit, asset value, distance to market from the center and access to range land negatively whereas access to electricity service, access to irrigation and total farm land size positively significant at $1 \%$ level of probability.

In the same way agro pastoralist the participant and non-participant mean is different and highly influenced by tropical livestock unit, asset value, access to irrigation, total farmland is negatively while distance to market and access to electricity positively significant at $1 \%$ level of probability (Result is documented in Table 4).

Table 4. Non-participant and Participant of livelihood strategies.

\begin{tabular}{|c|c|c|c|c|c|c|c|c|c|c|}
\hline \multirow{3}{*}{ Variable } & \multicolumn{5}{|c|}{ Pure Pastoralist } & \multicolumn{5}{|c|}{ Agro Pastoralist } \\
\hline & \multicolumn{2}{|c|}{ Non participant } & \multicolumn{2}{|c|}{ Participant } & \multirow{2}{*}{ t-value } & \multicolumn{2}{|c|}{ Non participant } & \multicolumn{2}{|c|}{ Participant } & \multirow{2}{*}{ t-value } \\
\hline & Mean & S.D & Mean & S.D & & Mean & S.D & Mean & S.D & \\
\hline SEX & 0.811 & 0.392 & 0.836 & 0.37 & -0.58 & 0.82 & 0.37 & 0.82 & 0.37 & -0.008 \\
\hline AGE & 38.25 & 8.213 & 38.42 & 6.44 & -0.20 & 38.40 & 6.47 & 38.27 & 8.26 & 0.15 \\
\hline FAMLSIZ & 6.55 & 1.71 & 6.6 & 1.71 & -0.26 & 6.59 & 1.70 & 6.57 & 1.72 & 0.089 \\
\hline EDUCHH & 2.39 & 2.89 & 2.75 & 2.99 & -1.08 & 2.71 & 2.97 & 2.45 & 2.94 & 0.79 \\
\hline DPRHH & 0.5 & 0.196 & 0.47 & 0.187 & 1.40 & 0.47 & 0.18 & 0.49 & 0.19 & -1.22 \\
\hline CREDIT & 0.54 & 0.49 & 0.56 & 0.49 & -0.27 & 0.56 & 0.49 & 0.54 & 0.49 & 0.19 \\
\hline ASSET & $187,749.00$ & 96,080 & 161,670 & 83,974 & $-2.60^{\star * *}$ & 160,413 & $83,349.00$ & 191,864 & 96,831 & $-3.11^{* * *}$ \\
\hline MEMCOP & 0.58 & 0.49 & 0.596 & 0.49 & -0.12 & 0.59 & 0.49 & 0.58 & 0.49 & 0.22 \\
\hline MEDIA & 0.92 & 0.26 & 0.95 & 0.21 & -1.12 & 0.95 & 0.20 & 0.91 & 0.27 & 1.31 \\
\hline ACCEXT & 0.47 & 0.5 & 0.38 & 0.48 & -1.58 & 0.38 & 0.48 & 0.45 & 0.50 & -1.24 \\
\hline DISMARKT & 4.31 & 7.91 & 20.84 & 17.29 & $-9.83^{* * *}$ & 20.78 & 17.37 & 3.56 & 5.77 & $10.17^{\star \star *}$ \\
\hline ACCELCT & 0.649 & 0.479 & 0.21 & 0.411 & $8.82^{\star \star \star}$ & 0.64 & 0.47 & 0.21 & 0.41 & $8.82^{\star \star *}$ \\
\hline IRRGT & 0.62 & 0.48 & 0.1 & 0.304 & $12.25^{\star * *}$ & 0.10 & 0.31 & 0.63 & 0.48 & $-12.34^{\star * *}$ \\
\hline FLNDSZ & 1.23 & 0.64 & 0.454 & 0.61 & $11.07^{\star * *}$ & 0.47 & 0.63 & 1.24 & 0.62 & $-10.62^{\star * *}$ \\
\hline
\end{tabular}

Source: own survey, Significance levels: ${ }^{\star},{ }^{* *},{ }^{* *}$ Significance at $10 \%, 5 \%$, and $1 \%$, respectively. 


\subsection{Determinant of Livelihood Strategies}

As shown in Table 5, the bivariate probit model estimate result revealed among 16 hypothesized explanatory variables ten variables for both pure pastoralist and agro-pastoralist found to be significantly influenced choice of livelihood strategies. The result indicates that age (AGE), family size (FAMLSIZ), dependency ratio (DPRHH), tropical livestock unit of holding (TLU), access to mass media (MEDIA), distance from the nearest market (DISMARKT), access to electricity (ACCELCT), access to irrigation (IRRGT), total farm land size (FARSZ) and access to rangeland (RNGLND) were determining factors for pastoral household choice of livelihood strategies.

However, the magnitude effect of some significant variables is not similar for the two livelihood strategies. Some may be highly significant to affect the choice of a strategy and may be insignificant for the other. Therefore, bivariate probit analysis results indicate selection of each type of livelihood strategy affected by different factors and at different levels of significance by the same factor (Table 5). It has noted that the bivariate probit estimates are report for two categories of livelihood strategies choice. The first alternative (i.e. selecting pure pastoralist only) used as a benchmark alternative against which the choice of the other three alternatives was seen. The plausible implication and marginal effects of the significant explanatory variables on the choice of households' livelihood strategies that affect pastoral household choice of livelihood strategies presented as follows:

Age of the household head (AGE): Age structure of pastoralist plays a great role in household decision choice of different types of livelihood options. It is a continuous variable. Age of the household head incorporated to account for the maturity of the head in his/her decision-making ability. As expected, Age of the household head (AGE) is negatively significant at $10 \%$ and $5 \%$ for pure pastoralist and agro pastoralist livelihood respectively (Table 5). An increase of one unit in age of the household head decrease the likelihood of a household being pure pastoral and agro pastoral by $2 \%$ (Table 5 ). Given all other variables in the model held constant, a one-year increase in age of the household will decrease household's choices of pure pastoralist at a base of agro pastoralist by 38.37 percent. This implies that pure pastoralist and agro pastoralist, whose age is relatively younger, could be pushed to engage in other non-pastoral activities. Additionally, elder participation in different livelihood options is lower as compared to the young generation due to their weak physical performance. Wassie et al. [26] agree this result with previous studies.

Total family size of the household (FAMLSIZ): It is a continuous variable. Family size is an important factor for the choice of livelihood option. As expected that, total family size of the household is positively significant at $10 \%$ level of significance for both pure pastoralist and agro pastoralist household respectively (Table 5). This is because of a big family size needs more resources for sustenance than a small family. People with big families will venture into as 
Table 5. Results of bivariate probit analysis.

\begin{tabular}{|c|c|c|c|c|c|c|c|c|}
\hline \multirow{2}{*}{ Variable } & \multicolumn{3}{|c|}{ Pure Pastoralist } & \multicolumn{3}{|c|}{ Agro-pastoralist } & \multirow{2}{*}{$\begin{array}{l}\text { Joint marginal } \\
\text { effects }\end{array}$} & \multirow{2}{*}{$\mathrm{dy} / \mathrm{dx}$} \\
\hline & Coefficient & Robust St.Error & P-Value & Coefficient & Robust St.Error & P-Value & & \\
\hline SEX & 0.420 & 0.301 & 0.16 & -0.170 & 0.323 & 0.60 & 0.83 & 0.0125 \\
\hline AGE & -0.028 & 0.015 & $0.06^{*}$ & -0.029 & 0.015 & $0.05^{\star *}$ & 38.37 & 0.0001 \\
\hline FAMLSIZ & 0.101 & 0.06 & $0.09^{*}$ & 0.110 & 0.059 & $0.07^{*}$ & 6.59 & -0.0003 \\
\hline EDUCHH & 0.010 & 0.033 & 0.76 & -0.010 & 0.033 & 0.85 & 2.63 & 0.0002 \\
\hline DPRHH & 1.033 & 0.515 & $0.05^{\star *}$ & 1.121 & 0.502 & $0.03^{\star \star}$ & 0.48 & -0.0046 \\
\hline CREDIT & -0.170 & 0.21 & 0.42 & 0.213 & 0.238 & 0.38 & 0.56 & 0.0019 \\
\hline LIVESTOCK & -0.095 & 0.037 & $0.02^{* *}$ & -0.063 & 0.038 & $0.10^{\star * \star}$ & 7.81 & 0.0011 \\
\hline ASSET & $9.76 \mathrm{E}-07$ & $8.98 \mathrm{E}-07$ & 0.28 & $-3.38 \mathrm{E}-07$ & $9.51 \mathrm{E}-07$ & 0.72 & 170,388 & 0.0000 \\
\hline MEMCOP & 0.14 & 0.208 & 0.49 & -0.14 & 0.228 & 0.54 & 0.59 & 0.0001 \\
\hline MEDIA & 0.78 & 0.392 & $0.05^{\star *}$ & 0.80 & 0.396 & $0.04^{* *}$ & 0.94 & -0.0011 \\
\hline ACCEXT & 0.00 & 0.227 & 0.99 & -0.02 & 0.224 & 0.92 & 0.41 & -0.0012 \\
\hline DISMARKT & -0.04 & 0.012 & $0.00^{\star * *}$ & -0.05 & 0.012 & $0.00^{\star * \star}$ & 15.32 & -0.0004 \\
\hline ACCELCT & 0.53 & 0.260 & $0.04^{* *}$ & 0.41 & 0.272 & $0.03^{* * *}$ & 0.36 & -0.0058 \\
\hline IRRGT & 1.25 & 0.232 & $0.00^{\star * *}$ & 1.30 & 0.221 & $0.00^{* \star *}$ & 0.28 & 0.003 \\
\hline FLNDSZ & -1.14 & 0.216 & $0.00^{\star * *}$ & -1.14 & 0.208 & $0.00^{* * *}$ & 0.72 & 0.0006 \\
\hline RNGLND & -1.03 & 0.288 & $0.00^{\star * *}$ & -0.98 & 0.352 & $0.01^{* * *}$ & 0.93 & 0.0023 \\
\hline Constant & $(1.32)$ & 0.919 & 0.15 & 0.82 & 0.989 & 0.41 & & \\
\hline
\end{tabular}

Source: own survey data (2019).Significance levels: ${ }^{*},{ }^{* *},{ }^{* * *}$ Significance at $10 \%, 5 \%$, and $1 \%$, respectively Likelihood ratio test of rho $=0:$ chi2 $(15)=55.823$ Prob $>$ chi $2=0.0000$.

many ways as possible to gain the required resources to support their families. The result is in line with Asfaw Albore [27].

Dependency ratio of the household (DPRHH): It is continuous variable and it refers to the proportion of economically inactive labour force (less than 14 and above 65 years old) to the active labour force (Between 15 and 65 years old) with in a household. As hypothesized previously the coefficient of dependency ratio of the household (DPRHH) was found to have positively related with both pure pastoralist and agro pastoralist livelihood strategies and statistically significant at $5 \%$ probability level (Table 5). In the pastoral area, having large livestock is considered as indication of asset and male household has owned more than one wife and using contraceptive method is considered as sine. This leads to bear a number of inactive labours in the household. As household member of inactive labour force increases by a ratio, the likely probability of the household needing more food for survival increases and the ability to meet their subsistence needs declines. Therefore, in order to fulfil the needs of the household members; households are induced to increase the level of income through choice of live- 
lihood strategies. The result of this study is consistent with the study of Bassie [28].

Tropical livestock unit of holding (TLU): It is a continuous variable expressed in terms of tropical livestock unit holding (TLU). As expected, in this study the coefficient of tropical livestock unit (TLU) was found to have negative relationship and statistically significant at $5 \%$ and $10 \%$ with both pure pastoralist and agro pastoralist choices of household livelihood strategies respectively (Table 5). This is because household having larger size of livestock are less likely to diversify the livelihood strategies into other non-pastoral activities compared to those who own small number of TLUs. Households owning more number of livestock considered as wealthy household in the community. This result is consistent with the finding study of Melese et al., [29].

Access to Mass Media (MEDIA): As hypothesized, the result of this study show that positively related with both pure pastoralist and agro pastoralist choices of household livelihood strategies and statistically significant at 5\% probability level (Result is documented in Table 5). This is because as access to media such as TV and radio enhances non-pastoral activities information, which enables that the pastoral households to participate in different livelihood options. Similarly, access to mass media may improve pastoral households' information on non-pastoral and agro pastoral livelihood opportunities. This result is consistent with the finding study of Emanuel [30].

Distance from the closest market (DISMARKT): Geographic variables are also important determinants of livelihood option. Markets play an important role in pastoral communities as place of sale for his or her livestock and its product and buy other necessary input.

As indicated in Table 5, the distance from the closest market features a negative and statistically significant effect on pure pastoralist and agro pastoralist strategies at $1 \%$ of level of significance. This suggests the probability of people to choice other livelihood strategies beyond the pure pastoralist and agro pastoralist is probably going to be reduced because the distance increase. This is often because individuals who live near the market area had higher probability to interact on other livelihood option beyond agriculture including; wage labourer and petty trade. The possible reason for the result could be that households far away from the market center will have not any easy and quick physical access to the market to move amount produced. In this study area, the pastoralist kebeles are in accessible road and located at a distance from center of the district. The result is in line with the findings of Tessema [31].

Access to rural electrification (ACCELCT): As hypothesized previously, Access to rural electrification have related positively and statistically significant at $5 \%$ level of significance with both pure pastoralist and agro pastoralist choice of livelihood (Result is documented in Table 5). This suggests Access, use and adoption of recent technology regarding to pastoral livelihood is very suffering from access of electricity. Electricity also had an impact on access to informa- 
tion. The foremost frequently bought electrical appliances after connection were TVs, radios and mobile phones and another major effect of electrification was that it significantly reduced expenditures on energy. Within the study area, there are high black market electronics exchange and entrance to the middle of the zone. Supported electronics exchange and entrance pastoral household of the study area having access to rural electrification service have choice to shift their livelihood to non-pastoral activity like petty trade on electronics, mobiles, etc.

Access to Irrigation (IRRGT): Irrigation benefits the farm households through higher production, higher yields, lower risk of failure, and better and year-round farm returns [32]. Needless to say access to irrigation have related positively and statistically significant at $1 \%$ level of significance with agro pastoralist livelihood strategies (Table 5). This meant that, households that were access to irrigation engaged in additional livelihood strategies than those located from inaccessible. Hence, better access to irrigable water resources would increase the return on capital (land) which could probably increase the return from labour and, make the farmer happier in his wealth position, hence, reduces the subsistence pressure to participating in several livelihood activities. The result is in line with the findings of Velasco et al. [33].

In other way, as indicated in Table 5 access to irrigation has related negatively and statistically significant at $1 \%$ level of significance with pure pastoralist livelihood strategies. This is because in pure pastoralist kebeles/peasant associations of the district have inaccessible irrigation. If chance of accessibility, they engaged in agro pastoralist and other non-pastoralist livelihood strategies.

Total farmland size (FLNDSZ): It is a continuous variable. Land is one among the most fundamental and important means of production/factor of production. The farm land size is an impact on crop production and when Land-man ratio being the per capita availability of cultivable land, a decrease in its value creates overpressure on land which in turn results in disguised unemployment in agriculture (i.e., workers having very low or zero marginal productivities). Therefore, this surplus labour will attempt to find jobs within the non-farm sector

As hypothesized previously total farmland size have related negatively and statistically significant at $1 \%$ level of significance with agro pastoralist and pure pastoralist livelihood strategies (Table 5). The possible reason for this is that with smaller land size are involved in other non-pastoral activities because of shortage of land to support their livelihood. Adugna [34] agree this result with previous studies.

Access to rangeland (RNGLND): Livestock grazing is one of the most widespread and important uses of rangelands. Renewable plant resources provide forage for ruminant livestock like cattle, sheep, and goats; and thus the ruminant animals subsequently provide food and fiber for people. As expected previously access to range land have negatively related and statistically significant at $1 \%$ level of significance with pure pastoralist and agro pastoralist livelihood strate- 
gies (Table 5). This is because of accessibility of rangeland leads the pastoral household have own large amount of livestock that have the main asset of in the areas. The household is not interesting to search other option of livelihood option.

\section{Conclusions and Recommendations}

\subsection{Conclusion}

Pure Pastoralist is the dominant economic activity and the primary source of livelihoods for pastoral households in the study area. However, due to recurrent drought and frequent climate change, the livestock production has been deteriorating over time, and has forced people to look for alternative employment option other than livestock rearing. A significant number of pastoral households engage in diverse livelihood strategies away from purely livestock production (Pure Pastoralist) towards agro Pastoralist (jointly crop production and livestock rearing) activities that are undertaken to broaden and generate additional income for survival and livelihood improvement. From the finding of the research, it is increasingly becoming clear that the pure Pastoralist alone cannot rely upon as the core activity for pastoral households as a means of improving livelihood in the study area.

Bivariate probit regression model applied to analyze and answer the questions why pastoral households pursue diverse livelihood strategies, which strategies are sustainable for household in the area. The model result indicated that out of 16 hypothesized variables 10 were found to be significantly influenced on pastoral area household is adoption of alternative livelihood strategies at 1\%, 5\% and $10 \%$ probability levels. These variables include family size, dependency ratio, access to mass media, access to electricity, access to irrigation, age of household, tropical livestock unit of holding, distance from the nearest market, total farmland size and access to rangeland. The finding of this study shows that family size, dependency ratio, access to mass media, access to electricity and access to irrigation have positively significant influence on choice of livelihood strategies. However, age of household, tropical livestock unit of holding, distance from the nearest market, total farmland size and access to rangeland were negatively significant effects and influences on choice of livelihood strategies.

In the study area, there is the potential/opportunity to diversify livelihood activities but not utilized yet by household due to lack of provision of training and credit service by concerned government bodies and stakeholders. Aromatic product like "Kerbie", "Unsi", Gum and incenses, "Kenefa" found abundantly in the area that pushes households to engage in petty trade but currently household used for home consumption only.

In addition to the above in this area, there is low technical and financial support to the existing and newly organized small-scale enterprises to engage in milk processing, grain mill operation, trade of livestock, cattle fattening, handcrafts, and petty trade as a means of livelihood strategies. 


\subsection{Recommendation}

Based on the findings of the study, the following policy recommendations are possible areas of intervention that might help to choose the best alternative livelihood strategies in the study area.

The negative and significant influences of age of household on Pastoralist livelihood strategies imply that elder age pastoral household participation is lower as compared to the young generation due to their weak physical performance. However, households travel long distance with livestock for the search of water and pasture but as the age becomes older and older, physical deterioration happens and resigns from pastoral livelihood by replacing younger. Thus the government and other responsible bodies consider this situation and design a livelihood policy strategy or package that benefits elder age pastoral households because it became a burden for household members.

The positive and significant influence of family size on pastoral livelihood strategies implies that as the large family size of household increases needs of more resources for sustenance than a small family. This situation leads pastoral households to search other options of livelihood activities other than Pastoralist to survive their family members. This is a fact that family size inhibits chance of highly adopting/engaging in different livelihood strategy that indicates that population pressure is one of basic concern in the area and in the area male household have married more than one wives. In this regard, awareness creation and provision of family planning services are mandatory by local government bodies and non-government organization that have intervention in area.

The negative and significant influences of tropical livestock unit on Pastoralist livelihood strategies implies that large livestock herd size creates better opportunity to earn more income from livestock production and household are not willing to investigate other option of livelihood activities. Thus, the significant role of livestock ownership in livelihood security suggests to design development strategy for livestock sector through improving livestock breeds, veterinary services, forage development, marketing, access to credit and overall management of livestock production that aimed at improving pastoral household welfare in general and food security status in particular.

In addition, Small-scale enterprises that performed by women that include milk processing, grain mill operation, trade of livestock, cattle fattening, handcrafts, and petty trade require technical and financial support therefore provision of training and credit service is highly important to enhance more opportunities of livelihood diversification.

The positive effect of access to mass media on the choice of livelihood strategy calls policies and specific interventions that facilitate access to climate information and knowledge through mass media, mobile or social networks will likely improve pastoral awareness of climate change and adoption of adaptive strategies. Additionally access to media leads pastoral household to participate on non-pastoral activities other than pastoral livelihood strategies. To ensure great- 
er uptake, this information should designed in a way that tailored to the interests of the pastoralists and agro-pastoralists in terms of content, language, and format.

The negative influence of distance to market on pastoral livelihood strategies implies that the probability of individuals to choice other livelihood strategies beyond the pure pastoralist and agro pastoralist is likely to be reduced as the distance increase. Market distance and related transport costs are the major factors hindering pastoralists from providing their product to the markets. Thus, provision of public facilities such as construction of roads and infrastructure in the pastoral areas facilitate transportation and operations that solve some of the problems of pastoral risks such as lack of market for cattle. Therefore, focus should pay on improving marketing access to pastoralists. In this regard, Special attention has taken to establish pastoral cooperatives and creating linkages with urban areas as well as international market.

The positive effect of access to rural electrification on pastoral livelihood strategies implies that as access to rural electrification increases pastoral house hold search other option of livelihood other than Pastoralist. Thus, expansion rural electrification infrastructure and services leads household to engage on electronics petty trade since the study area is adjacent to Ethiopian Somalia there is high amount of electronics transaction. This contributes for reduction of dependency of pastoral household on livestock and transform to other employment opportunities. Therefore, government and development partners give attention for expansion of rural electrification to reduce impact of drought and climate variability that happen on pastoral livelihood strategies.

The negative and significant impact of farm size on pastoral livelihood strategies suggests concerned bodies to develop appropriate strategies and policies especially for land resource-poor farmers. It also concerns promoting and creating positive environment for the emerging livelihood alternatives like non-farm activities. The presence of very small size of land calls for giving emphasis in agricultural intensification to enhance the productivity of the land so that generate adequate income and food.

\section{Conflict of Interest}

The authors would like to declare that they have no interest of conflict and we want to disclose you that it is our original research work.

\section{References}

[1] Regional Learning and Advocacy Program for Vulnerable Dry Land Communities (2012) Key Statistics on the Dry Lands of Kenya, Uganda and Ethiopia.

[2] Ethiopian Economic Association (2004) Transformation of the Ethiopian Agriculture: Potentials, Constraints and Suggested Intervention Measures. Report on the Ethiopia Economy, Addis Ababa.

[3] Pastoralism Forum Ethiopia, et al. (2010) Pastoralism and Land: Land Tenure, Administration and Use in Pastoral Areas of Ethiopia. 
[4] Ministry of Agriculture (2010) Annual Report, Addis Ababa.

[5] Bale Zone Pastoral Area Development Commission (2018) Annual Report, Robe.

[6] Bale Zone Preparedness and Early Warning Commission (2018) Annual Report.

[7] Bale Zone Planning and Economic Development Commission (2018) Annual Report of Non-Governmental Organization, Robe.

[8] Getachew Demissie Desta (2016) Livelihood Diversification: Strategies, Determinants and Challenges for Pastoral and Agro-Pastoral Communities of Bale Zone, Ethiopia, International Review of Social Sciences and Humanities.

[9] University of Illinois (2006) Gradually Guide for Conducting a Social Profile for Watershed Planning.

[10] Yin, R. (1994) Case Study Research: Design and Method. 2nd Edition, Sage, Beverly Hills.

[11] Bless, C. and Higson-Smith, C. (2000) Social Research Methods. An African Perspective. Cape.

[12] Leedy, P.D. and Ormrod, J.E. (2004) Survey of Research Methodology for Human Services Learners.

[13] Gibbs, A. (1997) Focus Groups. Social Research Update.

[14] Webb, C. and Kevern, J. (2001) Focus Groups as a Research Method: A Critique of Some Aspects of Their Use in Nursing Research. Journal of Advanced Nursing, 33, 798-805. https://doi.org/10.1046/j.1365-2648.2001.01720.x

[15] Goss, J.D. and Leinbach, T.R. (1996) Focus Groups as Alternative Research Practice: Experience with Transmigrants in Indonesia. Area, 28, 115-123.

[16] MacIntosh, J.A. (1993) Focus Groups in Distance Nursing Education. Journal of Advanced Nursing, 18, 1981-1985. https://doi.org/10.1046/j.1365-2648.1993.18121981.x

[17] Powell, R.A. and Single, H.M. (1996) Focus Groups. International Journal for Quality in Health Care, 8, 499-504. https://doi.org/10.1093/intqhc/8.5.499

[18] Stringer, E.T. and Genat, W.J. (2004) Action Research in Health. Merrill Prentice Hall, Upper Saddle River.

[19] Simões, C. and Soares, A.M. (2010) Applying to Higher Education: Information Sources and Choice Factors. Studies in Higher Education, 35, 371-389.

https://doi.org/10.1080/03075070903096490

[20] Kothari, C.R. (2004) Research Methodology: Methods and Techniques. New Age International Publishers, New Delhi.

[21] Sawena District Planning and Economic Development Commission (2019), Socio Economic Profile, Mica.

[22] Food and Agriculture Organization (2010) Pastoralism in the New Millennium. Animal Production and Health Paper, Rome.

[23] Greene, H.W. (2003) Econometric Analysis. Pearson Education Inc., New York.

[24] Kassie, M., Jaleta, M., Shiferaw, B., Mmbando, F. and Mekuria, M. (2013) Adoption of Interrelated Sustainable Agricultural Practices in Smallholder Systems: Evidence from Rural Tanzania. Technological Forecasting and Social Change, 80, 525-540. https://doi.org/10.1016/j.techfore.2012.08.007

[25] Hassan, R.M. (1996) Planting Strategies of Maize Farmers in Kenya: A Simultaneous Equations Analysis in the Presence of Discrete Dependent Variables. Journal of Agricultural Economics, 15, 137-149. 
https://doi.org/10.1016/S0169-5150(96)01194-2

[26] Wassie, B., Colman, D. and Fayissa, B. (2008) Diversification and Livelihood Sustainability in a Semi-Arid Environment: A Case Study from Southern Ethiopia. Journal of Development Studies, 43, 871-889.

[27] Asfaw, A. (2018) Review on Role and Challenges of Agricultural Extension Service on Farm Productivity in Ethiopia. International Journal of Agricultural Education and Extension, 4, 93-100.

[28] Bassie-Sweet, K. (2014) Maya Sacred Geography and the Creator Deities. University of Oklahoma Press, Norman.

[29] Tizazu, M.A., Ayele, G.M. and Ogato, G.S. (2018) Determinants of Rural Households Livelihood Diversification Strategies in Kuarit District, West Gojjam Zone of Amhara Region, Ethiopia. International Journal of Economic Behaviour and Organization, 6, 61-68. https://doi.org/10.11648/j.ijebo.20180603.11

[30] Emanuel, E. (2011) Rural Livelihood Diversification and Agricultural Household Welfare in Ghana. Journal of Development Agricultural Economics, 3, 325-334.

[31] Tessema, I. and Simane, B. (2019) Vulnerability Analysis of Smallholder Farmers to Climate Variability and Change: An Agro-Ecological System-Based Approach in the Fincha'a Sub-Basin of the Upper Blue Nile Basin of Ethiopia. Ecological Processes, 8, Article No. 5. https://doi.org/10.1186/s13717-019-0159-7

[32] Hussain, I. and Hanjra, M.A. (2004) Irrigation and Poverty Alleviation: Review of the Empirical Evidence. Irrigation and Drainage, 53, 1-15.

https://doi.org/10.1002/ird.114

[33] Velasco-Muñoz, J.F., et al. (2018) Sustainable Water Use in Agriculture: A Review of Worldwide Research. Journal of Sustainability, 10, 1084. https://doi.org/10.3390/su10041084

[34] Eniyew, A. (2012) Determinants of Livelihood Diversification in Pastoral Societies of Southern Ethiopia. Journal of Agriculture and Biodiversity Research, 1, 43-52. 